\title{
HPV 16 E7:86-93 Peptide Vaccine
}

National Cancer Institute

\section{Source}

National Cancer Institute. HPV 16 E7:86-93 Peptide Vaccine. NCI Thesaurus. Code C38761.

A synthetic peptide vaccine consisting of amino acids 86 through 93 (TLGIVCPI) of the viral oncoprotein human papillomavirus (HPV) 16 E7. Vaccination with HPV-16 E7:86-93 peptide, which binds to HLA-A* 0201 molecule, may stimulate the host immune system to mount a cytotoxic T-lymphocyte (CTL) response ag ainst tumor cells positive for HPV$16 \mathrm{E7}$. 